Article

\title{
Diverging Ambitions and Instruments for Citizen Participation across Different Stages in Green Infrastructure Projects
}

\author{
Jannes J. Willems ${ }^{1, *}$, Astrid Molenveld ${ }^{1,2}$, William Voorberg ${ }^{1}$ and Geert Brinkman ${ }^{1}$ \\ ${ }^{1}$ Department of Public Administration \& Sociology, Erasmus School of Behavioural and Social Studies, Erasmus University \\ Rotterdam, 3000 DR Rotterdam, The Netherlands; E-Mails: willems@essb.eur.nl (J.J.W.), molenveld@essb.eur.nl (A.M.), \\ voorberg@essb.eur.nl (W.V.), brinkman@essb.eur.nl (G.B.) \\ ${ }^{2}$ Research Group on Politics \& Public Governance, Department of Political Science, Faculty of Social Sciences, University \\ of Antwerp, 2000 Antwerp, Belgium \\ * Corresponding author
}

Submitted: 1 November 2019 | Accepted: 13 January 2020 | Published: 6 March 2020

\begin{abstract}
Both theory and practice increasingly argue that creating green infrastructure in order to make cities climate-proof requires joint public service delivery across the green infrastructure's lifecycle. Accordingly, citizen participation in each green infrastructure project stage is required, but the type of participation may differ. So far, limited research has been conducted to detangle how participation in green infrastructure projects is operationalised along the different project stages. This article, therefore, presents a comparative case study of nine European green infrastructure projects, in which we aim to determine: (1) how participatory ambitions may differ across green infrastructure project phases; and (2) which instruments are used to realise the participatory ambitions for each phase and whether these instruments differ across stages. The cases demonstrate different participation ambitions and means in the three project phases distinguished in this article (i.e., design, delivery, and maintenance). The design and maintenance stages resulted in high participation ambitions using organisational instruments (e.g., living labs, partnerships with community groups) and market-based instruments (e.g., open calls). In the delivery phase, participation ambitions decreased significantly in our cases, relying on legal instruments (e.g., statutory consultation) and communicative instruments (e.g., community events). Altogether, our exploratory study helps to define participation across the green infrastructure lifecycle: Early stages focus on creating shared commitment that legitimises the green infrastructure, while later stages are also driven by instrumental motives (lowering management costs). Although theory argues for profound participation in the delivery stage as well, our cases show the contrary. Future research can assess this discrepancy.
\end{abstract}

\section{Keywords}

climate adaptation; community involvement; green infrastructure; participation; policy instruments; urban water management

\section{Issue}

This article is part of the issue "Comparative Planning, Learning and Evolving Governance" edited by Kristof Van Assche (University of Alberta, Canada), Raoul Beunen (Open University of the Netherlands, The Netherlands) and Stefan Verweij (University of Groningen, The Netherlands).

(C) 2020 by the authors; licensee Cogitatio (Lisbon, Portugal). This article is licensed under a Creative Commons Attribution 4.0 International License (CC BY).

\section{Introduction}

Local governments are increasingly constructing green infrastructure, such as rain gardens, green roofs, and permeable pavement in order to make their cities more climate-sensitive (Benedict \& McMahon, 2002). Green infrastructure can have multiple benefits, for example, enhanced ecology, property values, and health and wellbeing (Kabisch et al., 2016; Zidar et al., 2017). The benefits of green infrastructure are widely recognised, yet 
the actual design, delivery, and maintenance of green infrastructure on the local level are found to be difficult (Jerome, Mell, \& Shaw, 2017). Where traditionally grey infrastructure is delivered in a technocratic, centralised, and engineering-driven manner (Brown, Ashley, \& Farrelly, 2011), the creation of green infrastructure increasingly takes place within a network of multiple stakeholders. These stakeholders can involve local communities, businesses, and NGOs (Innes \& Booher, 2004; Osborne, Radnor, \& Nasi, 2013). Hence, local governments responsible for constructing green infrastructure are increasingly moving towards an enabling or facilitating role in order to stimulate a variety of stakeholders in co-delivering green infrastructure (Mees, Uittenbroek, Hegger, \& Driessen, 2019).

This new role fits within a popular contemporary understanding of governmental involvement in public policy and public service delivery in general. In this understanding, a central premise is that each stakeholder brings in their own specific resources to the table and public value is mutually created (Voorberg, Bekkers, \& Tummers, 2015). Thus, the pooling of diverse resources is elemental for effective decision-making, policy design, and implementation (Osborne, Radnor, Kinder, \& Vidal, 2015). In addition, the government's main task is to facilitate network partners to collectively determine the scope, ambition, and instruments of these public services (Hartley, 2005; Osborne, 2006). Such a participatory conception of public service development and delivery is increasingly the standard in policy domains such as public health care (e.g., Dunston, Lee, Boud, Brodie, \& Chiarella, 2009; Hyde \& Davies, 2004) and education (e.g., Kotze \& du Plessis, 2003; Porter, 2013), as well as urban planning (e.g., Burton \& Mustelin, 2013) and urban water management (e.g., Sharp, 2017).

More participatory forms of public service delivery can also be seen in the domain of green infrastructure construction. Recent research on green infrastructure has discussed, for example, effective collaborative governance arrangements (Frantzeskaki, 2019), new participation techniques (Wilker, Rusche, \& Rymsa-Fitschen, 2016), local government roles in community initiatives (Mees et al., 2019), the use of citizens' local knowledge (Faehnle, Bäcklund, Tyrväinen, Niemelä, \& Yli-Pelkonen, 2014), and citizen volunteering (Jerome et al., 2017). However, to date, the dynamic nature of green infrastructure remains somewhat neglected in this body of research. Green infrastructure is a dynamic asset that, being nature-based, is self-generative (Fletcher et al., 2015). Accordingly, green infrastructure requires on-going participation over the course of its lifecycle. Yet, the type of participation may differ along the lifecycle (Uittenbroek, Mees, Hegger, \& Driessen, 2019; Wilker et al., 2016). To illustrate, the design phase may bring ideas together from different stakeholders, whereas the maintenance phase could entail citizen volunteers that monitor the green infrastructure. Given the different types of participation, we aim to determine: (1) how participatory ambitions may differ across green infrastructure project phases; and (2) which instruments are used to realise the participatory ambitions for each phase and whether these instruments differ across stages. As a result, this article answers the questions: (1) To what extent do participatory ambitions differ across different stages of green infrastructure development? (2) What kind of policy instruments are implemented by local governments in order to stimulate such a level of participation?

In order to answer our research questions, we conducted a comparative case study of nine green infrastructure projects situated in North-Western European midsized cities that are located in Belgium, Germany, the Netherlands, Norway, Sweden, and the UK. The projects are similar in terms of ambition (realising green infrastructure in a participatory manner); are all the responsibility of local governments (municipal level); and are all driven by public departments that share a background in engineering common in the field of urban water management (Brown et al., 2011). This article contributes to the literature on green infrastructure by enhancing our understanding of how ambitions about citizen participation may differ across the different phases of green infrastructure construction, what these possible differences explain, and how these differences are reflected in the selection of different policy instruments.

The article is structured as follows: The second section entails the theoretical framework, which combines insights from the literature on public participation and policy instruments. The third section discusses the methodology and introduces the nine cases. Fourth, the results are presented per green infrastructure project phase. The fifth and final section presents conclusions and reflections.

\section{Literature Review: Citizen Participation in Green Infrastructure Projects}

In general, the participation of citizens in public service delivery regained attention in the aftermath of the critique on New Public Management (NPM) as the dominant governance paradigm (Rhodes, 1996). In NPM, due to an increased emphasis on governmental efficiency, public services were fragmented (Dunleavy, Margetts, Bastow, \& Tinkler, 2006), lacked the typical legitimacy of non-market driven services (e.g., education, social support; Brandsen, Trommel, \& Verschuere, 2015), and generally were increasingly considered as unable to address new challenges in a complex world (Osborne, 2006; Rhodes, 1996). Therefore, in order to effectively address societal needs, the government is to be expected to collaborate with and within a network of other stakeholders, such as citizens and their communities, businesses, and NGOs (Innes \& Booher, 2004). The underlying idea is that when those resources are pooled and actors understand their inter-dependent position within a network with other actors, new and innovative solutions to contemporary policy challenges are developed 
(Osborne et al., 2015). Also, since a wide range of stakeholders can be involved in both the design and implementation of public services, these services are considered to be more legitimate than traditional public service development (Osborne et al., 2013). Such collaborations imply a profound level of participation of communities, businesses, and NGOs that goes beyond information provision or consultation (Arnstein, 1969). As a consequence, collaborative arrangements are proposed in which actors mutually create value, for example, reflected in either formal or more loosely coupled partnerships. Despite its promises and widespread use, research has presented mixed results of participation until now (Burton \& Mustelin, 2013; Rydin \& Pennington, 2000).

The need for more elaborate forms of citizen engagement can also be found in the literature on green infrastructure (e.g., Faehnle et al., 2014; Lovell \& Taylor, 2013; Mees et al., 2019). Here, a similar need for profound levels of participation is displayed, often because the wider societal benefits of green infrastructure require that "all groups of society should have a say in its planning and implementation to ensure that it meets their requirements" (Wilker et al., 2016, p. 230). If we look more closely into research on participation in the realisation of green infrastructure, scholars have focused predominantly on the early stages of green infrastructure development. In these stages, forms of collaborative governance and co-production are advocated (Frantzeskaki, 2019). Likewise, Wilker et al. (2016) argue that more interactive participation methods should be used at the very early stages of the planning process in order to achieve legitimate outcomes. As Jerome et al. (2017) argue, participation in later stages, such as the maintenance phase, remains under-researched, which could be substantiated with insights from green space management strategies that advocate environmental stewardship and citizen volunteering.

The different operationalisations of participation in green infrastructure development suggest that participation is shaped differently over the course of the green infrastructure lifecycle. Based on Uittenbroek et al. (2019), we define three phases in green infrastructure projects: project design; project delivery; and project maintenance. Consequently, we expect that the type of participation desired by local governments will differ across these three stages.

\subsection{Policy Instruments to Stimulate Participation}

The type of participation employed by local governments in green infrastructure projects can be understood by looking at the policy instruments they use (Salamon, 2002). Policy instruments are the "tools of government" (Hood, 1983) that aim to either restrict or enable certain activities and behaviour (Bouckaert, Peters, \& Verhoest, 2010). Furthermore, each policy instrument places responsibility on certain actors differently, for instance assigning responsibility to the government itself, busi- nesses, associations, communities, or combinations of these. Policy instruments, thus, differ in the way they steer. To illustrate, in the creation of green infrastructure, governments can make use of legal instruments, such as regulations and norms, and market-based instruments, such as tenders and grants (Krause, Hawkins, Park, \& Feiock, 2019). In addition, they have developed capacitybuilding and awareness-raising instruments to involve communities in taking climate adaptation measures (Dai, Wörner, \& van Rijswick, 2018).

Whereas the literature often suggests that policy instrument choice is based on its effectiveness (e.g., Henstra, 2016; Hood, 1983), Kassim and Le Galès (2010) argue that contextual factors also play an important role in policy instrument choice, stressing the power balance between actors. Thus, governments not only follow the logic of effectiveness, but also the logic of appropriateness in selecting and developing policy instruments (Capano \& Lippi, 2017; Krause et al., 2019). Policy instruments can be categorised in various ways (e.g., Bouckaert et al., 2010). Probably most famous is the distinction between the stick, the carrot, and the sermon (Bemelmans-Videc, Rist, \& Vedung, 2011). Another widely used distinction is how governments employ the resources of nodality (or information), authority, treasure, and organisation, which is translated into respectively communicative, legal, market-based, and organisational instruments (Hood, 1983; Howlett, 2000). In this article, we follow this distinction since it has been used more widely in climate adaptation research and it encompasses both coercive and less coercive instruments (see Table 1; Henstra, 2016; Mees et al., 2014).

First, legal and authoritative policy instruments involve norms and standards (Bouckaert et al., 2010). This category of instruments can be characterized as top-down, in which governments define the participation frameworks. Accordingly, responsibilities are clearly assigned-often to technical elites-and other actors are required to comply. Legal instruments are considered to be resource-intensive because of the monitoring and enforcement costs of laws and regulations. These instruments can also be somewhat imprecise, as standardised rules often target a large audience (Henstra, 2016). Likewise, there is little autonomy for implementers and they are inflexible to coordinate (Verhoest, Legrain, \& Bouckaert, 2003). Second, market-based instruments are instruments aimed at changing certain behaviour through market mechanisms (Bouckaert et al., 2010). Subsidies and grants are common examples of this and can activate communities to become involved. As they are usually targeted at distinct audiences, market-based instruments are said to be efficient and accountable instruments (Henstra, 2016). Third, communicative instruments focus on informing an audience about certain matters such as relevant issues, policies, activities, or events (Henstra, 2016). A typical example is the awarenessraising campaign. By informing an audience, these instruments generally help to increase legitimacy and can mo- 
Table 1. Four categories of policy instruments to stimulate participation (adapted from Henstra, 2016; Hood, 1983).

\begin{tabular}{|c|c|c|c|}
\hline & Category & Type of participation & Examples \\
\hline 1 & Legal & Participation through compliance & Penalties; mandates \\
\hline 2 & Market-based & $\begin{array}{l}\text { Participation through influencing market } \\
\text { mechanisms }\end{array}$ & Grants; competition; subsidies \\
\hline 3 & Communicative & Participation through information provision & Information boards; public campaigns \\
\hline 4 & Organisational & Participation through mobilisation of actors & Partnerships; agreements; social networks \\
\hline
\end{tabular}

tivate stakeholders to take actions. However, such instruments typically treat the audience as a passive receiver of information, rather than an audience to be engaged and activated-and thus become involved. Fourth, organisational instruments relate to the establishment of new organisational units or social networks in order to mobilise actors and stimulate direct involvement. Examples of this are community partnerships or voluntary agreements. Although organisational instruments are directly aimed at involving a variety of actors, they often remain largely invisible to the greater public and therefore may have limited legitimacy (Henstra, 2016).

Taken together, this article focuses on the type of participation ambitions that local governments espouse in the different phases of green infrastructure projects. Differences in participation type can become visible in how governments aim to achieve these ambitions, i.e., which policy instruments they use to fulfil their participation ambitions. In the next section, we elaborate on the used research methods in order to answer our research question.

\section{Methodology}

Our study is based on a case study comparison of nine green infrastructure projects in North-Western Europe, involving nine cities and six countries (introduced in Annex 1 in the Supplementary Material). The cases share the ambition to realise green infrastructure in a participatory manner. Together, these cases provide an overview of current green infrastructure practice in North-Western Europe.

\subsection{Data Collection and Analysis}

The data collection relied on two data sources. First, a questionnaire was distributed among project leaders in late 2018 to get an overview of the project, the ambitions, and the involved local governments and other stakeholders (see Annex 2 in the Supplementary Material for detailed questionnaires). Second, 21 representatives from the nine cities (approximately two participants from each city) were consulted during a workshop organised in Bradford (UK) in September 2019 to further discuss the type of participation and the policy instruments used. In the workshop, three topics were discussed:
1. Inventory of the ambitions. In this step, participants talked and wrote about the projects' aspirations and ambitions by the start of the project concerning citizen participation;

2. Inventory of the policy instruments used. Participants were asked to define their instruments for citizen participation and relate them to the categorisation of Table 1;

3. Rating the effectiveness of the instruments (what works well, what does not work). The final step included a measurement of the perceived effectiveness and hence a self-estimation of the civil servants championing the projects.

For each step, participants filled in hand-outs (summarised in Annex 2). Group discussions were audiorecorded. Also, the authors' observations were used to verify the findings. For the analysis, the cases were first clustered based on the project phase. First, participation ambitions were identified from the hand-outs. Ambitions stated in the workshop were verified with findings from the questionnaire from 2018. Second, the instruments used for citizen participation were examined per project phase and categorised into one of the four instrument types. Third, the perceived effectiveness of individual instruments was used to identify underlying motivations for the instrument choice.

\section{Results}

The results section presents, first, the participation ambitions of the cases and, second, the policy instrument choices that lead to a type of participation. The third and final part of this section contains a discussion of the findings.

\subsection{Different Citizen Participation Ambitions across Project Phases}

When it comes to citizen participation, we see that the projects have very different starting points in terms of ambitions. Annex 1 presents the ambitions of the nine cities concerning citizen participation. The ambitions of the cases can be clustered following the three project phases distinguished in the theoretical framework. 


\subsubsection{Design Phase}

In the project design phase, respondents indicate that citizen participation is focused on building coalitions, engaging citizens with their living environment, and mutually designing the green infrastructure. The three projects that are in this stage, located in Antwerp, Dordrecht, and Gothenburg, entail large-scale urban redevelopment projects with a central role for green infrastructure, which they aim to realise through the involvement from different municipal departments (e.g., urban planning, transportation, urban drainage, and health), landowners, NGOs, and community groups. To illustrate, Antwerp City Council had long-term ambitions to redevelop the Sint-Anneke Plage on the left banks of the Scheldt River. The opportunity to create green infrastructure in this area was seized by the project team to also boost the local socio-economic situation and improve recreation facilities. As the project impacts local residents, landowners, and entrepreneurs, the City Council wants to heavily involve them in the design, delivery, and maintenance of the green infrastructure. Similarly, Dordrecht City Council had many separate investments planned in the Vogelbuurt neighbourhood related to improving the social cohesion and living conditions as well as to replacing the sewage system. The ambition to create green infrastructure resulted in a goal to combine these investments into one comprehensive plan which highlighted the inclusion and collaboration of NGOs, residents, and neighbourhood organisations. Finally, the project in Gothenburg is aimed at "activating" the Frihamnen area, a former uninhabited harbour area that will be transformed into a residential neighbourhood. The co-design of green infrastructure is used to engage local residents with the area, so they get to know this currently uninhabited area.

\subsubsection{Delivery Phase}

Citizen participation in the project delivery phase is perceived as somewhat different compared to the previous phase. The projects that are currently delivering their green infrastructures are located in Aberdeen, Bergen, Bradford, and Hamburg. These projects include both large-scale redevelopment projects (Bergen, Bradford) and small-scale green infrastructure (Aberdeen, Hamburg). According to respondents, the aim to deliver the green infrastructure project requires no or limited community involvement. As a result, the local government leading the project adheres to a more traditional role, in which citizen participation is predominantly an instrumental aim that helps to deliver the project more smoothly. This can be explained by two mechanisms. First, some cases, such as Bergen and Bradford, feel a limited need for citizen participation that moves beyond consultation at this stage. The projects in Bergen and Bradford are driven by transportation goals, with a smaller role for green infrastructure. To illustrate, the project in Bergen is driven by the creation of a new light rail that will connect the Mindemyren neighbourhood to the city centre. Bergen City Council uses this redevelopment as an opportunity to create green infrastructure along the corridor. Attention in this phase is mainly paid to swift implementation. Second, some cases have limited experience with participation. To illustrate, in the cases of Aberdeen and Hamburg, public water authorities or water departments are in the lead of creating the green infrastructure. These cases are in general more engineering-oriented, focusing on creating climate adaptation measures and less on community involvement. This is, for example, reflected in the term Sustainable Urban Drainage Systems (SUDS) used by Aberdeen, which stresses the technical orientation, albeit more nature-based (using ecosystem principles in the technical design). The central aim is to create more water storage and climate adaptation measures, seen in small-scale projects such as the creation of rain gardens along a street.

\subsubsection{Maintenance Phase}

The projects in the maintenance phase are Enfield and Kent, which also have high ambitions in terms of community involvement. While citizen participation in the design phase aimed at networking and bridging interests, the projects in Enfield and Kent aim for a more facilitating role since the local governments aspire to involve the community in the maintenance of the green infrastructure. They have already realised green infrastructures, such as rain gardens (e.g., at George V Park, Kent) and wetlands (e.g., in Broomfield Park, Enfield). These instances are relatively small-scale, concrete infrastructure measures that require more maintenance than traditional grey infrastructure would. Therefore, respondents argue that they aim to stimulate communities, such as voluntary groups, to co-maintain the more costly green infrastructure. To illustrate, a respondent from Enfield stated that this could not only lower maintenance budgets but also stimulate social cohesion in the neighbourhood adjacent to the wetland.

Overall, we observe that citizen participation ambitions follow the curve of a U-shaped parabola (red line, Figure 1).

\subsection{Policy Instrument Choice for Citizen Participation}

If we look at how the cases translate their participation ambitions into policy instruments, we observe that the projects have employed different instruments for citizen participation across the project phases (Table 2).

\subsubsection{Design Phase}

The cases seem to prefer two types of instruments in the design phase: organisational and market-based instruments. Concerning organisational instruments, the cases of Antwerp, Dordrecht, and Gothenburg have estab- 


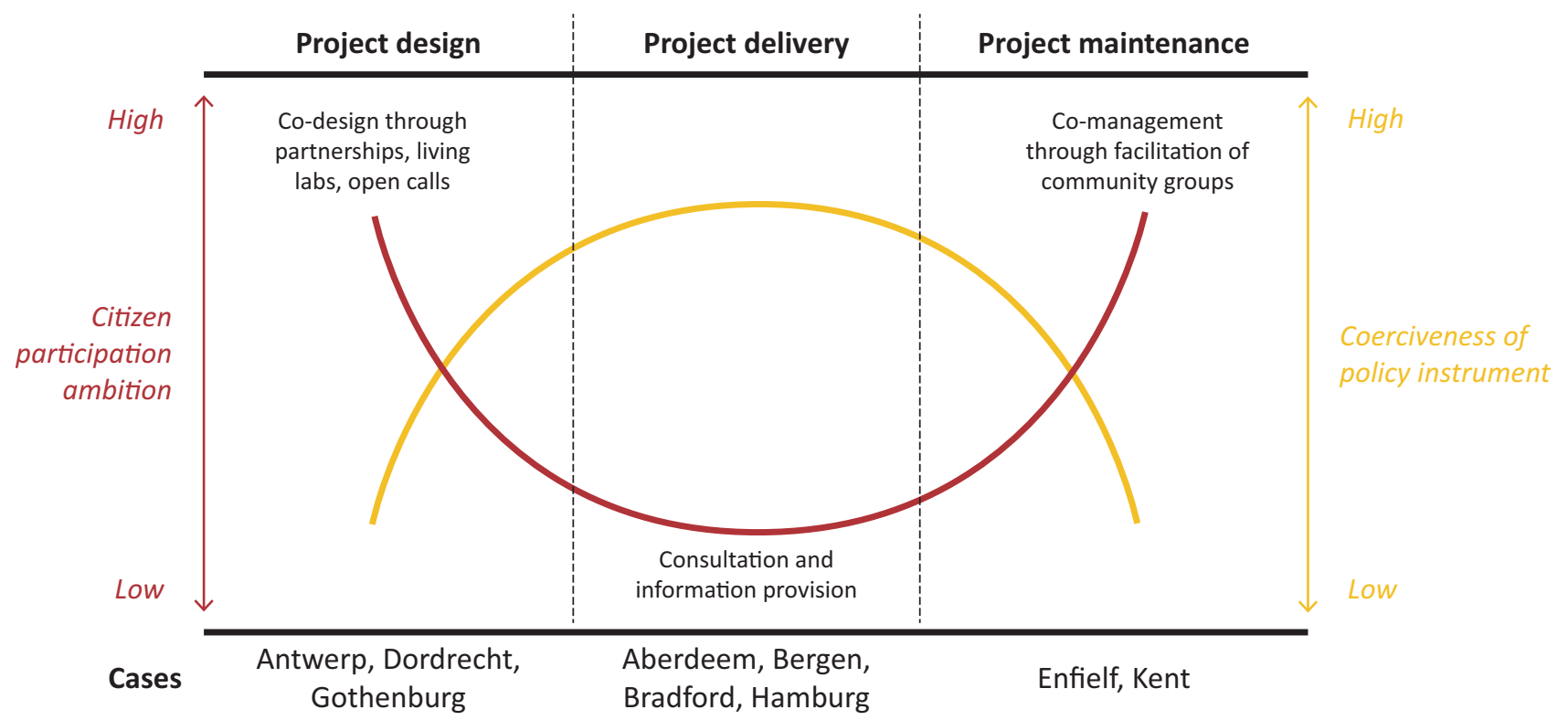

Figure 1. Citizen participation in the three green infrastructure project phases, including examples of policy instruments used.

lished new organisational units, such as the launch of an urban living lab (Antwerp), a dedicated team working on "blue-green challenges" (Dordrecht), and a new project team (Gothenburg). Respondents argue that these new units could more easily reach out to other stakeholders, which is effective for building coalitions and in shared meaning-making between stakeholders. For example, respondents in Antwerp stated that the living lab created a setting in which the local government can work together with local stakeholders more collaboratively, resulting in a jointly designed green infrastructure plan, developed from the "bottom up." However, respondents mentioned that mobilising actors did not directly result in political support for the plan. For instance, the plans jointly developed by a constellation of the City Council, an NGO, the waterway authority, and consultants in the living lab in Antwerp were not approved by politicians, which put the project on hold. Similarly, municipal departments that were not involved in the living lab considered the plans unfeasible and felt they were given limited incentives to implement them. The new department in Dordrecht did not receive abundant financial resources, so the team became occupied with building up a coalition of stakeholders that could become supporters of realising green infrastructure and put pressure on stakeholders to invest in this. In Gothenburg, a project team was formed by officials from the municipal City Planning Office (Stadsbyggnadskontoret) and the public enterprise River City Company (Ä/vstranden Utveckling), which is the landowner in the Frihamnen district. As the team was loosely connected to their "mother organisations," the project team felt more freedom to involve communities as much as possible, which resulted in the development of a participatory place-building method.

In addition to organisational instruments, marketbased instruments were also used. In Gothenburg, the team used the instrument of an open call to invite architects and artists to design prototypes for Frihamnen. These prototypes had to be developed in close cooperation with residents. To illustrate, one architecture firm developed a sauna which was co-designed with residents. According to a respondent, the area used to be a no-go area in the city, as the area was uninhabited. Through the creation of prototypes and the involvement of citizens, the project team triggered interest in the area (hence place-building). Respondents from Gothenburg were very positive about this: The open call not only created value in the area (through the construction of prototypes) but also generated social cohesion and a sense of ownership among residents that participated in the design. This is accredited by respondents to the high level of organisation of the architecture firms that won the open call, building further on their experience gained in other projects. Dordrecht made use of a European funding opportunity, in which the grant application was jointly developed by both the local City Council and neighbourhood organisations. Thus, such applications can help in creating a shared commitment. Although the grant was not approved, respondents from Dordrecht City Council are still positive about this instrument. For example, a respondent argued that working together generated a lot of energy among stakeholders and that the shared ambition continues to exist. Taken the two instrument categories together, the organisational instruments focused mainly on creating a network that could contribute to the co-design of green infrastructure, while the marketbased instruments were used for the actual co-design.

\subsubsection{Delivery Phase}

The cases in the delivery phase, having limited participation ambitions, predominantly relied on statutory con- 
sultation, a legal, coercive instrument. Examples include formal public hearings as well as more informal community meetings and events. For example, in Aberdeen, consultation took place with local stakeholders in community consultations, such as with the local Fernielea School. To illustrate, school pupils and their parents were involved in choosing different SUDS designs. In Bradford, the wider public was mainly informed through traditional and social media and can provide input during statutory community meetings. Respondents argued that they are well-experienced with consultation meetings, as they have ample experience with this. In general, they argue that face-to-face consultation ("two-way communication") is preferred over "passive" consultation via (online) questionnaires. For consultation meetings, respondents provided a wide range of communicative instruments to inform residents, such as drawings, 3D-animations and videos, and both social and traditional media. Respondents from Bergen were very enthusiastic about the creation of a scale model of their regeneration project, which worked well to make the plans concrete and to start discussions with residents. Likewise, a respondent from Bradford City Council argues that videos made the plans more tangible and imaginable for residents. According to respondents, a downside of these instruments was that they fail to reach everybody within the community. Particularly in neighbourhoods without any (formal) community groups known to the authority, respondents argued that it can be challenging to engage with residents. Respondents suggest working with local schools to reach their parents and, subsequently, build up trust and engage with the wider community. In addition, online communicative instruments were considered challenging, as information can easily be misinterpreted and, according to a respondent from Enfield, can start "living its own life." Respondents, there- fore, preferred direct communication, for example at community events.

\subsubsection{Maintenance Phase}

In the maintenance phase, the cases in Enfield and Kent have adopted a facilitating role by using organisational instruments. On the one hand, Kent County Council has created more organisational capacity by appointing a community liaison officer who is responsible for community engagement. On the other hand, Kent and Enfield have established partnerships with local communities for the maintenance of the newly created parks. These partnerships are made with Friends of the Parks groups. For example, Enfield City Council created wetlands for water storage in Broomfield Park, which is currently maintained by the Friends of Broomfield Park, a group of volunteers. Similar to the projects in the design phase, local governments have been using organisational instruments for mobilising actors. Respondents from Enfield and Kent were positive about this, as it lowers municipal maintenance costs and simultaneously creates community cohesion. For instance, the shed used by Friends of Broomfield Park in Enfield is an important social hub for the local community. Especially in areas where community groups already exist, facilitation of these groups is considered promising, according to respondents. Respondents indicated, though, that longterm interest from these groups remains difficult, and that they prefer to engage with so-called "champions" as an entry point in the community.

\subsection{Discussion}

Over the course of the green infrastructure lifecycle, we have observed different ambitions regarding citizen par-

Table 2. The policy instruments used per phase and linked to the cases.

\begin{tabular}{|c|c|c|c|}
\hline & Design & Delivery & Maintenance \\
\hline Legal & & $\begin{array}{l}\text { Statutory consultation } \\
\text { (Aberdeen, Bergen, } \\
\text { Bradford) }\end{array}$ & \\
\hline Market-based & $\begin{array}{l}\text { Joint grant application } \\
\text { (Dordrecht); open call to } \\
\text { develop prototypes } \\
\text { (Gothenburg) }\end{array}$ & & \\
\hline Communicative & & $\begin{array}{l}\text { Community events } \\
\text { (Aberdeen, Bergen, } \\
\text { Bradford); newsletters } \\
\text { (Aberdeen, Bergen); } \\
\text { scale model (Bergen); } \\
\text { visualisations (Bradford) }\end{array}$ & \\
\hline Organisational & $\begin{array}{l}\text { Urban living lab (Antwerp); } \\
\text { new department } \\
\text { (Dordrecht); dedicated } \\
\text { project team (Gothenburg) }\end{array}$ & & $\begin{array}{l}\text { Establishment of } \\
\text { partnerships (Enfield, Kent); } \\
\text { appointment of community } \\
\text { liaison (Kent) }\end{array}$ \\
\hline
\end{tabular}


ticipation. In the project design and maintenance, high ambitions exist; the project delivery phase suffices with lower ambitions (red line, Figure 1). High participation ambitions are usually accompanied by softer, more voluntary policy instruments, while coercive instruments are used for lower ambitions (yellow line, Figure 1).

Despite similar high ambitions between the design and maintenance phase, we also see different foci. High forms of citizen participation in the design phase are advocated in the cases and seem widely accepted, as participation legitimises the green infrastructure more (Frantzeskaki, 2019; Wilker et al., 2016). Moreover, local stakeholders can pool in new resources that lead to higher public value (Osborne et al., 2015). Respondents, though, mention the difficulty of getting to results. This may be due to the initial stages of the project, in which more undefined boundaries exist. The policy instruments currently used by the cases demand vast resources (time, human, financial), which are often secured through new organisational units (new teams, the start of a living lab) or external grant applications. The type of participation in the design phase is thus often allocated to new, temporary organisational structures or new collaborative arrangements. Respondents expressed concerns about such arrangements. For example, the project in Dordrecht was put on hold once a European subsidy was not granted. In a similar vein, the living lab in Antwerp was discontinued after local elections in 2018. Being located outside regular organisational practices gives a project freedom (see Gothenburg), yet this position also runs the risk of remaining a "stand-alone," disconnected from these regular practices (van Popering-Verkerk \& van Buuren, 2017).

In contrast, participation in the maintenance phase seems more feasible and more instrumentally motivated. Participation in this phase can be targeted specifically to local community groups and residents, while participation in the design phase was focused on more institutionalised actors (e.g., NGOs representing communities or private landowners). As the green infrastructure is already constructed at this stage, the boundaries within participation can take place and seem better defined compared to previous phases. Accordingly, citizen participation becomes easier to relate to these better-defined tasks. Participation, then, often takes shape in the form of green space co-management, which has been previously discussed by Jerome et al. (2017). Once communities were recruited, respondents from the projects in Enfield and Kent were rather satisfied with the level of participation.

Citizen participation ambitions in the project delivery phase were overall much lower. Interestingly, several researchers have argued that more participation is required in this stage of implementation (Burton \& Mustelin, 2013; Wilker et al., 2016), but this is not seen in our cases. Consequently, this confirms the on-going struggle of local governments to involve communities in the actual delivery, often explained by their engineering- driven, expert-led background (Brown et al., 2011). In this phase, the decision-making is left to experts and participation ambitions are more instrumental and aimed at implementing the project smoothly. Respondents from the project, though, self-assess this positively. They consider themselves well-equipped, having developed an extensive set of instruments for consultation and communication. Moreover, they do not perceive a need to involve citizens in such depth in this phase. One explaining factor could be that previous phases already entailed more profound participation, yet our research design allows us to only present a snapshot of the cases.

\section{Conclusion}

The design, delivery, and maintenance of green infrastructure are instances of a public service that is increasingly considered a mutual effort of public and private actors. Hence, local governments are exploring new ways of enhancing citizen participation, which moves away from a more hierarchical and engineering-driven style towards a more network-steering and facilitating role (Brown et al., 2011; Mees et al., 2019). This article examined what ambitions exist in nine European projects for stimulating citizen participation in the design, delivery, and maintenance phases of green infrastructure projects, and whether different policy instruments are used per phase.

Our exploratory study revealed different types of participation in green infrastructure projects with different types of policy instruments used to enhance this. First, cases in the design phase (Antwerp, Dordrecht, Gothenburg) stated high ambitions and often made use of organisational instruments that could bring stakeholders together. This type of instrument was considered a more legitimate means of public service delivery, developing green infrastructure in a participatory, joint fashion. However, the organisational instruments received mixed reviews, because ideas developed in new organisational units, such as a living lab, can help in building coalitions and shared meaning-making, but can become detached from regular work practices (see also Kemp \& Scholl, 2016). In the design phase, marketbased instruments were also used, such as the joint writing of grant applications and open calls. They were rated positively by respondents since these instruments created shared incentives, commitment, and provided the freedom for participants to co-design the green infrastructure. Second, projects in the delivery phase (Aberdeen, Bergen, Bradford, Hamburg) had low overall participation ambitions and displayed a more traditional, government-led style of working. These projects mainly used legal and communicative instruments, such as statutory consultation and community events and newsletters. Third, projects in the maintenance phase (Enfield, Kent) aimed again for higher forms of participation, both from a legitimation and from an instrumental point of view. The co-management of green infras- 
tructure, namely, could stimulate community engagement, but simultaneously lower public maintenance budgets. To this end, mainly organisational instruments were used, such as partnerships with local community groups or the creation of a community liaison. These instruments facilitated communities to become involved in their locality.

Overall, we observe that green infrastructure projects aim for high participation in the early and later phases of the project (Figure 1). Our cases suggest that higher ambitions of participation could be better realised through (often more voluntary) organisational and market-based instruments. Several respondents questioned the extent to which their instruments are effective to accomplish public participation. Most governments had the ambition to reach out to different societal groups, but respondents stated that they had trouble reaching them all. Often, they preferred to work with institutionalised actors. Therefore, we could argue that the instruments currently used may not be very effective in democratising public service delivery. This confirms previous research that urban water management remains a highly expert-driven field (Brown et al., 2011). Further research is required to determine whether the instruments used are unequipped to realise more equal relationships between stakeholders. For instance, open calls may lead to more community involvement, yet a vertical dependent relationship continues, in which the local authority (solely) defines the conditions.

Our article is an exploratory assessment of participation ambitions and policy instruments that enhance public participation in the public service delivery of green infrastructure. The analysis provided an empirical illustration of the diversity of policy instruments for preferred participation per phase. Future research can look more systematically into these relationships, for example addressing to what extent the participation ambitions are actually achieved by these instruments. As our research focused on one specific moment in time, longitudinal studies could improve our understanding of the evolution of collaborative arrangements over the course of the green infrastructure. The comparison in this article helped to identify patterns in participation ambitions and subsequent policy instruments. The local spatial governance system, in which the projects are embedded, seemed an important conditioning factor for the ambitions and approaches developed in the project. For instance, projects that were led by authorities responsible for urban drainage or transportation generally defined narrower participation ambitions and used more coercive instruments. Projects led by authorities responsible for urban development often defined broader participation goals and developed more voluntary instruments (e.g., the implementation of a living lab or an open call). This distinction suggests that at least two different spatial governance systems are in place for green infrastructure projects that lead to different participation types. Future research could detangle these two governance systems more in-depth and incorporate more contextual factors that may have influenced the type of participation and policy instrument choice, such as existing power asymmetries between actors (Kassim \& Le Galès, 2010).

\section{Acknowledgments}

The authors gratefully acknowledge the input received from city-partners that participated in this research. This study is made possible with funding from the European Interreg Project BEGIN (Blue-Green Infrastructure through Social Innovation). The authors would also like to thank the three reviewers for their feedback, which has greatly improved the manuscript.

\section{Conflict of Interests}

The authors declare no conflict of interests.

\section{Supplementary Material}

Supplementary material for this article is available online in the format provided by the authors (unedited).

\section{References}

Arnstein, S. R. (1969). A ladder of citizen participation. Journal of the American Institute of Planners, 35(4), 216-224.

Bemelmans-Videc, M. L., Rist, R. C., \& Vedung, E. O. (Eds.). (2011). Carrots, sticks, and sermons: Policy instruments and their evaluation. New Brunswick, NJ: Transaction Publishers.

Benedict, M. A., \& McMahon, E. T. (2002). Green infrastructure: Smart conservation for the 21st Century. Renewable Resources Journal, 20(3), 12-17.

Bouckaert, G., Peters, B. G., \& Verhoest, K. (2010). The coordination of public sector organizations. London: Palgrave Macmillan.

Brandsen, T., Trommel, W., \& Verschuere, B. (2015). The State and the reconstruction of civil society. International Review of Administrative Sciences, 83(4), 676-693.

Brown, R., Ashley, R., \& Farrelly, M. (2011). Political and professional agency entrapment: An agenda for urban water research. Water Resources Management, 25(15), 4037-4050.

Burton, P., \& Mustelin, J. (2013). Planning for climate change: Is greater public participation the key to success? Urban Policy and Research, 31(4), 399-415.

Capano, G., \& Lippi, A. (2017). How policy instruments are chosen: Patterns of decision makers' choices. Policy Sciences, 50(2), 269-293.

Dai, L., Wörner, R., \& van Rijswick, H. F. (2018). Rainproof cities in the Netherlands: Approaches in Dutch water governance to climate-adaptive urban planning. International Journal of Water Resources Development, 34(4), 652-674. 
Dunleavy, P., Margetts, H., Bastow, S., \& Tinkler, J. (2006). New public management is dead-Long live digitalera governance. Journal of Public Administration Research and Theory, 16(3), 467-494.

Dunston, R., Lee, A., Boud, D., Brodie, P., \& Chiarella, M. (2009). Co-production and health system reformFrom re-imagining to re-making. Australian Journal of Public Administration, 68(1), 39-52.

Faehnle, M., Bäcklund, P., Tyrväinen, L., Niemelä, J., \& Yli-Pelkonen, V. (2014). How can residents' experiences inform planning of urban green infrastructure? Case Finland. Landscape and Urban Planning, 130, 171-183.

Fletcher, T. D., Shuster, W., Hunt, W. F., Ashley, R., Butler, D., Arthur, S., . . \& \& Mikkelsen, P. S. (2015). SUDS, LID, BMPs, WSUD and more: The evolution and application of terminology surrounding urban drainage. Urban Water Journal, 12(7), 525-542.

Frantzeskaki, N. (2019). Seven lessons for planning nature-based solutions in cities. Environmental Science \& Policy, 93, 101-111.

Hartley, J. (2005). Innovation in governance and public services: Past and present. Public Money and Management, 25(1), 27-34.

Henstra, D. (2016). The tools of climate adaptation policy: Analysing instruments and instrument selection. Climate Policy, 16(4), 496-521.

Hood, C. (1983). The tools of government. London: Palgrave Macmillan.

Howlett, M. (2000). Managing the "hollow state": Procedural policy instruments and modern governance. Canadian Public Administration, 43(4), 412-431.

Hyde, P., \& Davies, H. T. (2004). Service design, culture and performance: Collusion and co-production in health care. Human Relations, 57(11), 1407-1426.

Innes, J. E., \& Booher, D. E. (2004). Reframing public participation: Strategies for the 21st Century. Planning Theory \& Practice, 5(4), 419-436.

Jerome, G., Mell, I., \& Shaw, D. (2017). Re-defining the characteristics of environmental volunteering: Creating a typology of community-scale green infrastructure. Environmental Research, 158, 399-408.

Kabisch, N., Frantzeskaki, N., Pauleit, S., Naumann, S., Davis, M., Artmann, M., . . \& \& Zaunberger, K. (2016). Nature-based solutions to climate change mitigation and adaptation in urban areas: Perspectives on indicators, knowledge gaps, barriers, and opportunities for action. Ecology and Society, 21(2). http://dx.doi. org/10.5751/ES-08373-210239

Kassim, H., \& Le Galès, P. (2010). Exploring governance in a multi-level polity: A policy instruments approach. West European Politics, 33(1), 1-21.

Kemp, R., \& Scholl, C. (2016). City labs as vehicles for innovation in urban planning processes. Urban Planning, 1(4), 89-102.

Kotze, T. G., \& du Plessis, P. J. (2003). Students as "co-producers" of education: A proposed model of student socialisation and participation at tertiary institutions. Quality Assurance in Education, 11(4), 186-201.

Krause, R. M., Hawkins, C. V., Park, A. Y. S., \& Feiock, R. C. (2019). Drivers of policy instrument selection for environmental management by local governments. Public Administration Review, 79(4), 477-487.

Lovell, S. T., \& Taylor, J. R. (2013). Supplying urban ecosystem services through multifunctional green infrastructure in the United States. Landscape Ecology, 28(8), 1447-1463.

Mees, H. L., Dijk, J., van Soest, D., Driessen, P. P., van Rijswick, M. H., \& Runhaar, H. (2014). A method for the deliberate and deliberative selection of policy instrument mixes for climate change adaptation. Ecology and Society, 19(2). http://dx.doi.org/10.5751/ES06639-190258

Mees, H. L., Uittenbroek, C. J., Hegger, D. L., \& Driessen, P. P. (2019). From citizen participation to government participation: An exploration of the roles of local governments in community initiatives for climate change adaptation in the Netherlands. Environmental Policy and Governance, 29(3), 198-208.

Osborne, S. P. (2006). The new public governance? Public Management Review, 8(3), 377-387.

Osborne, S. P., Radnor, Z., \& Nasi, G. (2013). A new theory for public service management? Toward a (public) service-dominant approach. The American Review of Public Administration, 43(2), 135-158.

Osborne, S. P., Radnor, Z., Kinder, T., \& Vidal, I. (2015). The SERVICE framework: A public-service-dominant approach to sustainable public services. British Journal of Management, 26(3), 424-438.

Porter, D. O. (2013). Co-production and network structures in public education. In V. Pestoff, T. Brandsen, \& B. Verschuere (Eds.), New public governance, the third sector, and co-production (pp. 163-186). London: Routledge.

Rhodes, R. A. W. (1996). The new governance: Governing without government. Political Studies, 44(4), 652-667.

Rydin, Y., \& Pennington, M. (2000). Public participation and local environmental planning: The collective action problem and the potential of social capital. Local Environment, 5(2), 153-169.

Salamon, L. M. (2002). The tools of government: A guide to new governance. Oxford: Oxford University Press.

Sharp, L. (2017). Reconnecting people and water: Public engagement and sustainable urban water management. London: Routledge.

Uittenbroek, C. J., Mees, H. L., Hegger, D. L., \& Driessen, P. P. (2019). The design of public participation: Who participates, when and how? Insights in climate adaptation planning from the Netherlands. Journal of Environmental Planning and Management, 62(14), 2529-2547.

van Popering-Verkerk, J., \& van Buuren, A. (2017). Developing collaborative capacity in pilot projects: Lessons from three Dutch flood risk management experi- 
ments. Journal of Cleaner Production, 169, 225-233.

Verhoest, K., Legrain, A., \& Bouckaert, G. (2003). Over samenwerking en afstemming: Instrumenten voor een optimale coördinatie van beleid en beheer in de publieke sector [On collaboration and alignment: Instruments for an optimal coordination of policy and management in the public sector]. Ghent: Academia Press.

Voorberg, W. H., Bekkers, V. J., \& Tummers, L. G. (2015). A systematic review of co-creation and co-production:
Embarking on the social innovation journey. Public Management Review, 17(9), 1333-1357.

Wilker, J., Rusche, K., \& Rymsa-Fitschen, C. (2016). Improving participation in green infrastructure planning. Planning Practice \& Research, 31(3), 229-249.

Zidar, K., Belliveau-Nance, M., Cucchi, A., Denk, D., Kricun, A., O'Rourke, S., . . \& \& Montalto, F. (2017). A framework for multifunctional green infrastructure investment in Camden, NJ. Urban Planning, 2(3), $56-74$.

\section{About the Authors}

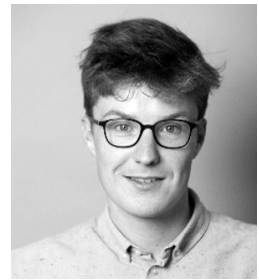

Jannes Willems is a Postdoctoral Researcher in the Department of Public Administration \& Sociology, Erasmus University Rotterdam. He is involved in several research projects (both European and Dutch) related to urban climate adaptation, water management, and infrastructure re-development, in which he examines how public managers are collaborating with other stakeholders. His expertise lies in institutional analysis, discourse analysis, and organisational learning. ORCiD: https://orcid.org/0000-00023318-9706

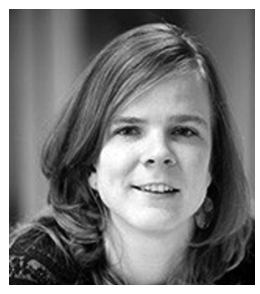

Astrid Molenveld is affiliated with the Department of Public Administration and Sociology of Erasmus University Rotterdam and the research group on Politics and Public Governance of Antwerp University. She has a particular interest in applying multiple research-methods in her work, like QCA, Q-methodology and statistics. Her current research activities include comparative research on coordination and collaborative governance, with a special focus on cross-cutting and 'wicked' policy issues. She recently published in Public Administration Review, Public Administration, and Public Management Review.

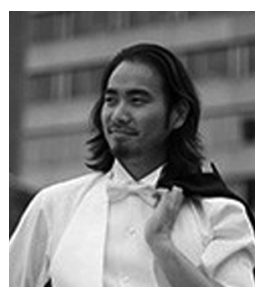

William Voorberg is a Postdoctoral Researcher in the Department of Public Administration and Sociology at Erasmus University Rotterdam, where he coordinates the Erasmus Governance Design Studio. His research focuses on public value creation, public innovation, and the application of designthinking in public administration.

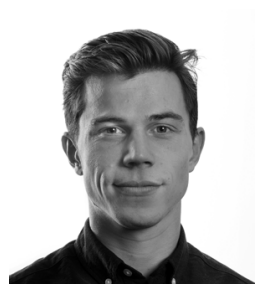

Geert Brinkman is a PhD Student at the Department of Public Administration and Sociology at Erasmus University Rotterdam. He is part of the Erasmus Governance Design Studio where he explores the applicability and application of design-led approaches in public administration. 